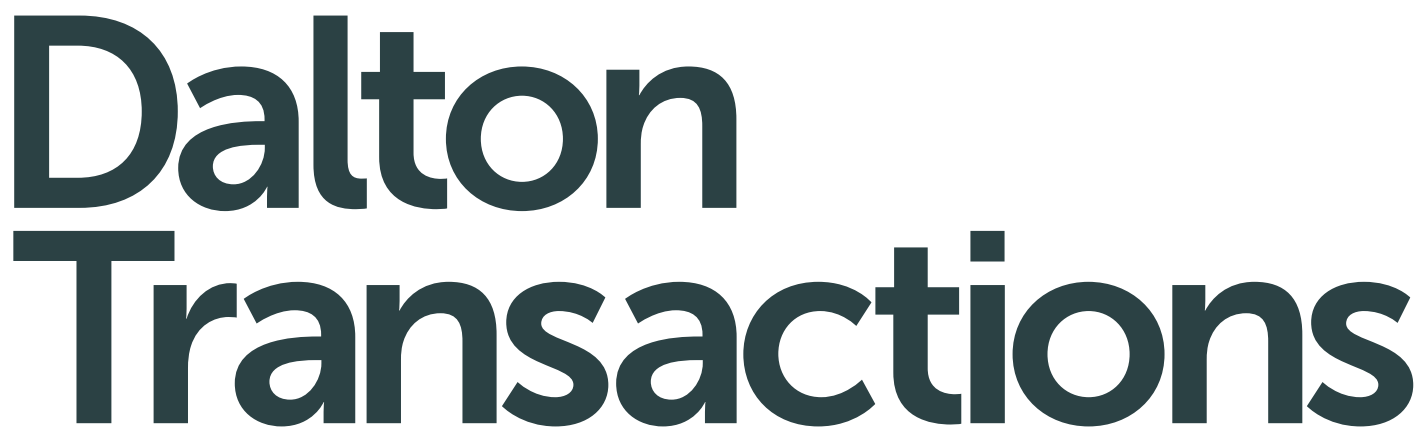

An international journal of inorganic chemistry www.rsc.org/dalton

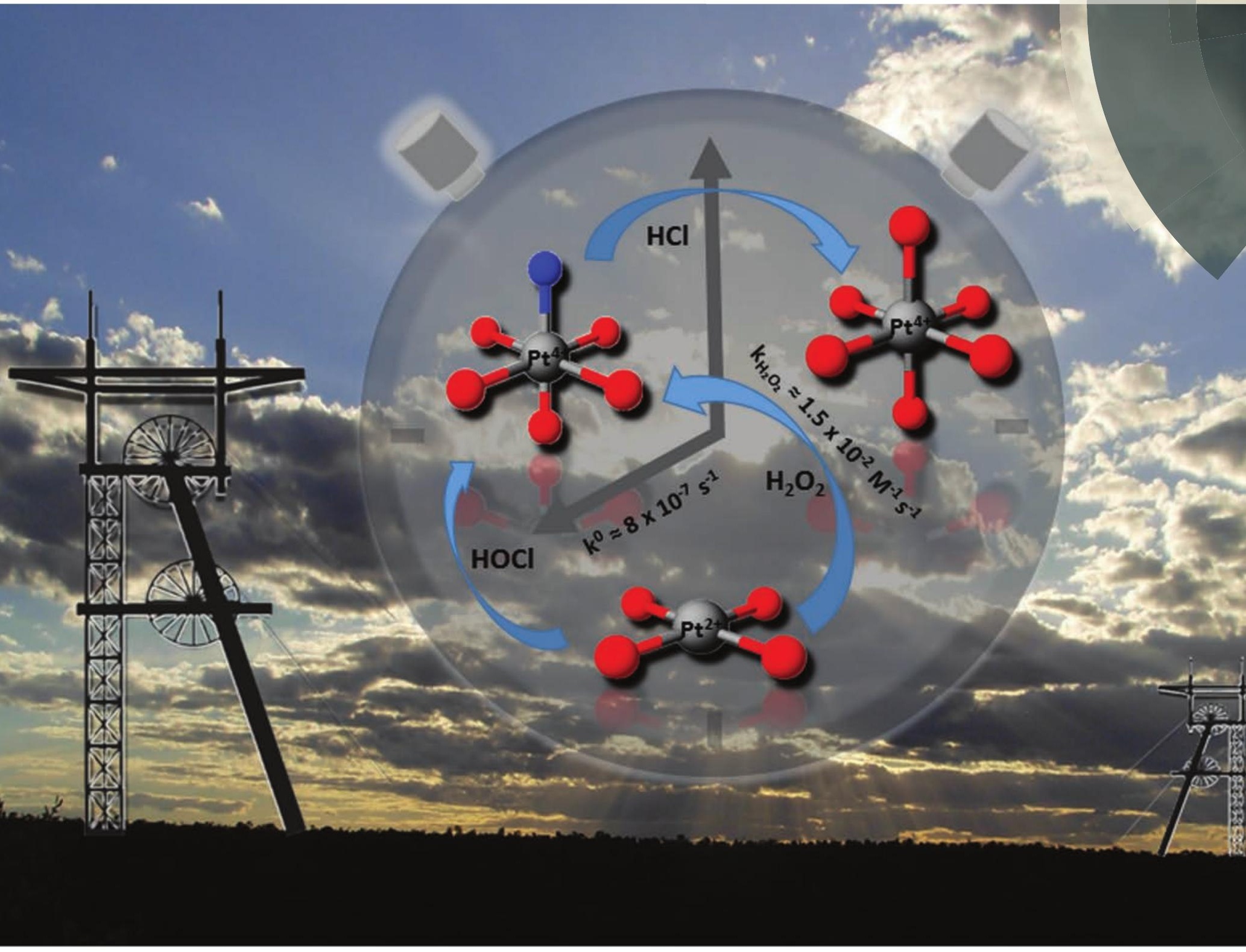

ISSN $1477-9226$

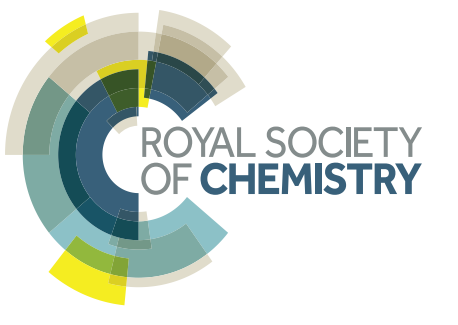


Cite this: Dalton Trans., 2014, 43 6308

Received 29th October 2013, Accepted 6th December 2013 DOI: $10.1039 / c 3 d t 53057 d$ www.rsc.org/dalton

\section{Mechanism of tetrachloroplatinate(II) oxidation by hydrogen peroxide in hydrochloric acid solution $\dagger$}

\begin{abstract}
Pieter Murray, ${ }^{a, b}$ Klaus R. Koch*a and Rudi van Eldik*b
Oxidation of tetrachloroplatinate(॥) by hydrogen peroxide in hydrochloric acid was studied by UV-Vis spectrophotometry. Oxidation takes place via two parallel reactions with hypochlorous acid and hydrogen peroxide, respectively, according to the overall rate law $\mathrm{d}[\mathrm{Pt}(\mathrm{IV})] / \mathrm{d} t=\left(k^{0}+k_{\mathrm{H}_{2} \mathrm{O}_{2}}[\mathrm{Pt}(\mathrm{II})]\right)\left[\mathrm{H}_{2} \mathrm{O}_{2}\right]$. For oxidation of $\left[\mathrm{PtCl}_{4}\right]^{2-}$ at relatively low concentrations, $\left[\mathrm{PtCl}_{4}\right]^{2-} \ll 0.5 \mathrm{mM}$, hypochlorous acid formation is fast relative to the oxidation of $\left[\mathrm{PtCl}_{4}\right]^{2-}$ by hydrogen peroxide, as a result of the rate determining reaction $\mathrm{H}_{2} \mathrm{O}_{2}+\mathrm{H}^{+}+\mathrm{Cl}^{-} \rightarrow \mathrm{HOCl}+\mathrm{H}_{2} \mathrm{O}$, resulting in a rate law $\mathrm{d}[\mathrm{Pt}(\mathrm{IV})] / \mathrm{d} t=k^{0}\left[\mathrm{H}_{2} \mathrm{O}_{2}\right]$ with a value $k^{0}=(8 \pm 2) \times$ $10^{-7} \mathrm{~s}^{-1}$ at $35{ }^{\circ} \mathrm{C}$. For concentrations of $\left[\mathrm{PtCl}_{4}\right]^{2-}>0.5 \mathrm{mM}$, oxidation by hydrogen peroxide becomes dominant, resulting in the pseudo-first order rate law $d[\mathrm{Pt}(\mathrm{IV})] / \mathrm{d} t=k_{\mathrm{H}_{2} \mathrm{O}_{2}}[\mathrm{Pt}(\mathrm{II})]\left[\mathrm{H}_{2} \mathrm{O}_{2}\right]$ with the value $k_{\mathrm{H}_{2} \mathrm{O}_{2}}=(1.5 \pm 0.1) \times 10^{-2} \mathrm{M}^{-1} \mathrm{~s}^{-1}$ at $35^{\circ} \mathrm{C}$. The final oxidation product is a mixture of $\left[\mathrm{PtCl}_{5}\left(\mathrm{H}_{2} \mathrm{O}\right)\right]^{-}$and $\left[\mathrm{PtCl}_{6}\right]^{2-}$, with $\left[\mathrm{PtCl}_{6}\right]^{2-}$ formed as a result of $\left[\mathrm{PtCl}_{4}\right]^{2-}$ assisted chloride anation reactions.
\end{abstract}

\section{Introduction}

Oxidation of Pt(II) square-planar complexes by hydrogen peroxide has been exploited in many areas of research, particularly as a strategy towards the design of new complexes. ${ }^{1}$ Many of these studies rely on the formation of hydroxido complexes by the oxidation with hydrogen peroxide, which provides more stability and control. The square-planar configuration of the original Pt(II) complex is retained furnishing a Pt(Iv) product with new ligands coordinated trans to each other. For instance, oxidation of $\left[\mathrm{PtCl}_{4}\right]^{2-}$ by hydrogen peroxide in water yields trans $-\left[\mathrm{PtCl}_{4}(\mathrm{OH})_{2}\right]^{2-}$ quantitatively according to eqn (1). ${ }^{2}$

$$
\left[\mathrm{PtCl}_{4}\right]^{2-}+\mathrm{H}_{2} \mathrm{O}_{2} \rightarrow \text { trans- }\left[\mathrm{PtCl}_{4}(\mathrm{OH})_{2}\right]^{2-}
$$

${ }^{195} \mathrm{Pt}$ NMR indicates that the trans coordinated hydroxido ligands originate from hydrogen peroxide and solvent water respectively. ${ }^{3}$ Inert hydroxido ligands can be protonated after oxidation to render the aqua ligands that are labile, promoting substitution reactions. ${ }^{4}$

By comparison, oxidation of $\left[\mathrm{PtCl}_{4}\right]^{2-}$ by hydrogen peroxide in acidic medium yields trans $-\left[\mathrm{PtCl}_{4}\left(\mathrm{H}_{2} \mathrm{O}\right)_{2}\right]$, while relatively fast $\mathrm{Pt}(\mathrm{II})$ assisted ligand scrambling reactions cause a

\footnotetext{
${ }^{a}$ Department of Chemistry and Polymer Science, University of Stellenbosch, Private Bag X1, 7602 Matieland, South Africa. E-mail: krk@sun.ac.za

${ }^{b}$ Department of Chemistry and Pharmacy, University of Erlangen-Nürnberg, Egerlandstr. 1, 91058 Erlangen, Germany.

E-mail: rudi.vaneldik@chemie.uni-erlangen.de

$\dagger$ Electronic supplementary information (ESI) available. See DOI:10.1039/ c3dt53057d
}

redistribution of the oxidation product(s) to form a mixture of $\left[\mathrm{PtCl}_{6-n}\left(\mathrm{H}_{2} \mathrm{O}\right)_{n}\right]^{2-n}(n=0-4)$ complexes. ${ }^{5}$ The large-scale separation of platinum from other platinum group metals (PGMs) depends, amongst other factors, on the efficient oxidation of $\mathrm{Pt}(\mathrm{II})$ to $\mathrm{Pt}(\mathrm{IV})$ in solution. The oxidation states of the various PGMs dissolved in the hydrochloric acid process solutions are manipulated to allow for their separation by inter alia solvent extraction (SX), oxidative distillation and/or classical ionexchange methods. ${ }^{5}$ Although hydrogen peroxide is not used in the refining industry, as part of ongoing work in this context, we examined in detail the oxidation of $\left[\mathrm{PtCl}_{4}\right]^{2-}$ by hydrogen peroxide in hydrochloric acid as a benchmark system. In the oxidation of Pt(II) to Pt(Iv) in solution, Pearson and Basolo proposed a reaction mechanism involving $\mathrm{Pt}$ (II) assisted ligand exchange more than 50 years ago. ${ }^{6}$ This mechanism was later revised to account for direct formation of $\left[\mathrm{PtCl}_{6}\right]^{2-}$ from trans- $\left[\mathrm{PtCl}_{4}\left(\mathrm{H}_{2} \mathrm{O}\right)_{2}\right]$ in a chloride rich solution. ${ }^{4}$ The origin of the difference in behaviour between trans-Pt(Iv) aqua and hydroxido analogues is attributed to the labile trans aqua ligands which are susceptible to bond breakage. ${ }^{7}$ Kinetic studies dealing with oxidation of Pt(II) complexes by hydrogen peroxide have been neglected, particularly in the presence of free chloride. A kinetic study dealing with the oxidation of $\left[\mathrm{PtCl}_{4}\right]^{2-}$ by hydrogen peroxide in perchloric acid has been reported. ${ }^{8}$

In the present study, oxidation of $\left[\mathrm{PtCl}_{4}\right]^{2-}$ by hydrogen peroxide is revisited, with the added complexity of free chloride ions in solution, presenting a more complex mechanism. Formation of $\left[\mathrm{PtCl}_{5}\left(\mathrm{H}_{2} \mathrm{O}\right)\right]^{-}$and possibly trans- $\left[\mathrm{PtCl}_{4}\left(\mathrm{H}_{2} \mathrm{O}\right)_{2}\right]$ coincides with $\left[\mathrm{PtCl}_{4}\right]^{2-}$ assisted ligand exchange. Apart from 
the complications associated with such reactions, hydrochloric acid catalyses the decomposition of hydrogen peroxide to form hypochlorous acid according to eqn (2).

$$
\mathrm{H}_{2} \mathrm{O}_{2}+\mathrm{H}^{+}+\mathrm{Cl}^{-} \stackrel{k_{1}}{\longrightarrow} \mathrm{HOCl}+\mathrm{H}_{2} \mathrm{O}
$$

Oxidation by hydrogen peroxide and hypochlorous acid may therefore coincide to yield two parallel reactions $k_{\mathrm{H}_{2} \mathrm{O}_{2}}$ and $k_{\mathrm{HOCl}}$ as depicted in the scheme in (3), where the intermediates are $\mathbf{1}=$ trans $-\left[\mathrm{PtCl}_{4}\left(\mathrm{H}_{2} \mathrm{O}\right)_{2}\right]$ and $2=\left[\mathrm{PtCl}_{5}\left(\mathrm{H}_{2} \mathrm{O}\right)\right]^{-}$.

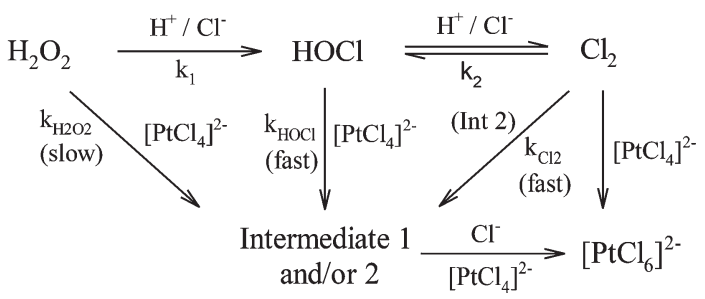

Oxidation of $\left[\mathrm{PtCl}_{4}\right]^{2-}$ by hydrogen peroxide is slow, whereas oxidation by hypochlorous acid is rapid in comparison, but yields the same product. ${ }^{8,9}$ Furthermore, depending on the reaction conditions, hypochlorous acid may form chlorine which can also act as an oxidant, further complicating this process. These aspects are explored and discussed in the present study to elucidate the overall oxidation mechanism of $\left[\mathrm{PtCl}_{4}\right]^{2-}$ by hydrogen peroxide in the presence of an excess of hydrogen cations and chloride anions.

\section{Experimental section}

\section{Chemicals and solutions}

All chemicals were of reagent grade quality and used without further purification. Potassium tetrachloroplatinate(II) $\left(99.9+\%, \mathrm{~K}_{2} \mathrm{PtCl}_{4}\right)$, sodium chloride $(99+\%, \mathrm{NaCl})$ and sodium perchlorate $\left(99+\%, \mathrm{NaClO}_{4}\right)$ were obtained from SigmaAldrich. Hydrogen peroxide ( $30 \% \mathrm{w} / \mathrm{w}, \mathrm{H}_{2} \mathrm{O}_{2}$, Sigma-Aldrich) was of reagent grade quality and used as received. Solutions of hydrogen peroxide were prepared immediately before use. Analytically pure concentrated perchloric acid $\left(70 \% \mathrm{w} / \mathrm{w}, \mathrm{HClO}_{4}, 1\right.$ $\mathrm{L}=1.68 \mathrm{~kg}$, Merck) and hydrochloric acid (HCl, Sigma-Aldrich) were used to prepare solutions. Stock solutions of $1 \mathrm{mM}$ or $10 \mathrm{mM}\left[\mathrm{PtCl}_{4}\right]^{2-}$ were prepared in $1 \mathrm{M}$ or $2 \mathrm{M} \mathrm{HCl}$ from which further dilutions were made. Solutions containing $\mathrm{Pt}$ (II) were kept in the dark to eliminate photo-induced aquation reactions. ${ }^{10,11}$ Concentrations of $\left[\mathrm{PtCl}_{4}\right]^{2-}$ were evaluated by UV-Vis spectrophotometry at $331 \mathrm{~nm}\left(\varepsilon_{331}=59 \mathrm{M}^{-1} \mathrm{~cm}^{-1}\right)$ or $390 \mathrm{~nm}$ $\left(\varepsilon_{390}=56 \mathrm{M}^{-1} \mathrm{~cm}^{-1}\right) .{ }^{12}$ Chloride concentrations $>0.1 \mathrm{M}$ are sufficient to suppress aquation of $\left[\mathrm{PtCl}_{4}\right]^{2-} \rightarrow\left[\mathrm{PtCl}_{3}\left(\mathrm{H}_{2} \mathrm{O}\right)\right]^{-}$, and in $1 \mathrm{M} \mathrm{HCl}$, all $\mathrm{Pt}(\mathrm{II})$ essentially exists as $\left[\mathrm{PtCl}_{4}\right]^{2-} \cdot{ }^{13}$ All aqueous solutions were made with ultra-pure de-ionised water.

\section{Spectrophotometry}

Photo-induced reactions necessitate kinetic measurements in UV-Vis absorption spectra at a specific wavelength. UV-Vis spectra in the range $200-600 \mathrm{~nm}$ were recorded after the oxidation was complete. Measurements were performed on a Shimadzu UV-2010PC spectrophotometer. The instrument was equipped with a thermoelectrically controlled cell holder using $1 \mathrm{~cm}$ tandem quartz cuvettes. Activation volume measurements for slow reactions were performed on a Shimadzu UV-2010PC spectrophotometer equipped with a high pressure cell fitted with a $1.5 \mathrm{~cm}$ pill-box quartz-cuvette. ${ }^{14}$ Activation volume measurements for relatively fast reactions were performed on a laboratory-made high-pressure stopped-flow instrument. ${ }^{15}$ The temperature was controlled and maintained in these instruments at $35.0 \pm 0.1^{\circ} \mathrm{C}$ using a circulating water bath (Julabo MP-5).

\section{Kinetics}

Observed rate constants for pseudo-zero order reactions were obtained directly from the slope of concentration versus time plots. Observed rate constants for reactions showing pseudofirst order character were calculated directly from absorbance versus time plots using a least-squares program. The ionic strength was kept constant at $1 \mathrm{M}$ in all experiments by using the correct ratios of hydrogen chloride, sodium chloride, sodium perchlorate and perchloric acid. Hydrogen peroxide was always present in large excess ( $>15$ times) with regard to the substrate ensuring pseudo-order reaction conditions.

\section{Spectra}

Both $\left[\mathrm{PtCl}_{5}\left(\mathrm{H}_{2} \mathrm{O}\right)\right]^{-}$and $\left[\mathrm{PtCl}_{6}\right]^{2-}$ were identified in the final spectra after oxidation of $\left[\mathrm{PtCl}_{4}\right]^{2-}$ by hydrogen peroxide. The $\left[\mathrm{PtCl}_{5}\left(\mathrm{H}_{2} \mathrm{O}\right)^{-}\right] /\left[\mathrm{PtCl}_{6}{ }^{2-}\right]$ ratio is proportional to the oxidation rate which in turn is influenced by the concentration of $\left[\mathrm{PtCl}_{4}\right]^{2-}, \mathrm{H}_{2} \mathrm{O}_{2}$, acid and chloride. Slow reactions led to almost complete conversion of $\left[\mathrm{PtCl}_{4}\right]^{2-} \rightarrow\left[\mathrm{PtCl}_{6}\right]^{2-}(>90 \%$ of $\mathrm{Pt}(\mathrm{Iv})$ identified as $\left[\mathrm{PtCl}_{6}\right]^{2-}$ ), while for fast oxidation reactions $\left[\mathrm{PtCl}_{5}\left(\mathrm{H}_{2} \mathrm{O}\right)\right]^{-}$is the major product. Since chloride anation of $\left[\mathrm{PtCl}_{5}\left(\mathrm{H}_{2} \mathrm{O}\right)\right]^{-}$is slow in the absence of $\left[\mathrm{PtCl}_{4}\right]^{2-}$, conversion of $\left[\mathrm{PtCl}_{5}\left(\mathrm{H}_{2} \mathrm{O}\right)\right]^{-} \rightarrow\left[\mathrm{PtCl}_{6}\right]^{2-}$ is effectively quenched after oxidation when $\left[\mathrm{PtCl}_{4}\right]^{2-}$ is depleted. ${ }^{4}$ For the oxidation of $\left[\mathrm{PtCl}_{4}\right]^{2-}$ an absorbance increase is observed between 200 and $500 \mathrm{~nm}$ except for the region between 222 and $236 \mathrm{~nm}$ in which isosbestic points occur and an absorbance decrease is observed, as shown in Fig. 1.

The $\left[\mathrm{PtCl}_{5}\left(\mathrm{H}_{2} \mathrm{O}\right)^{-}\right] /\left[\mathrm{PtCl}_{6}{ }^{2-}\right]$ ratio for $\mathrm{Pt}(\mathrm{II}) \leq 0.07 \mathrm{mM}$ was determined at 230 and $262 \mathrm{~nm}$ where these complexes show absorbance maxima and minima, respectively. The UV spectra of these complexes are known and have been reported elsewhere. ${ }^{2,16}$ For $\left[\mathrm{PtCl}_{5}\left(\mathrm{H}_{2} \mathrm{O}\right)\right]^{-}, \varepsilon_{230}=12500 \mathrm{M}^{-1} \mathrm{~cm}^{-1}$ and $\varepsilon_{262}=$ $11600 \mathrm{M}^{-1} \mathrm{~cm}^{-1}$, whereas for $\left[\mathrm{PtCl}_{6}\right]^{2-}, \varepsilon_{230}=3300 \mathrm{M}^{-1} \mathrm{~cm}^{-1}$ and $\varepsilon_{262}=24500 \mathrm{M}^{-1} \mathrm{~cm}^{-1}$. Since the visible spectra of $\left[\mathrm{PtCl}_{5}\left(\mathrm{H}_{2} \mathrm{O}\right)\right]^{-}$and $\left[\mathrm{PtCl}_{6}\right]^{2-}$ are very similar $\left(\varepsilon_{353}=490 \mathrm{M}^{-1}\right.$ $\mathrm{cm}^{-1}$ for both complexes), it was not possible to determine accurate values for the $\left[\mathrm{PtCl}_{5}\left(\mathrm{H}_{2} \mathrm{O}\right)^{-}\right] /\left[\mathrm{PtCl}_{6}\right]^{2-}$ concentration ratio from the visible spectra for concentrations of $\mathrm{Pt}(\mathrm{II}) \geq$ $0.2 \mathrm{mM}$. Dilution of such solutions, however, indicated that $\left[\mathrm{PtCl}_{6}\right]^{2-}$ is the dominant species. Typical spectral changes observed for the oxidation of $\left[\mathrm{PtCl}_{4}\right]^{2-}$ at relatively high concentration are illustrated in Fig. 2. 


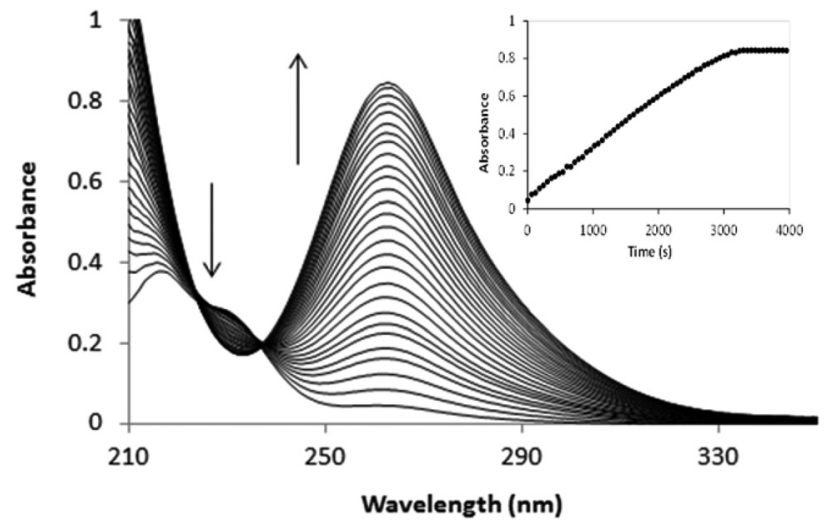

Fig. 1 Spectral changes recorded for the oxidation of $0.04 \mathrm{mM}$ $\left[\mathrm{PtCl}_{4}\right]^{2-}$ by $4 \mathrm{mM} \mathrm{H}_{2} \mathrm{O}_{2}$ in $1 \mathrm{M} \mathrm{HCl}$.

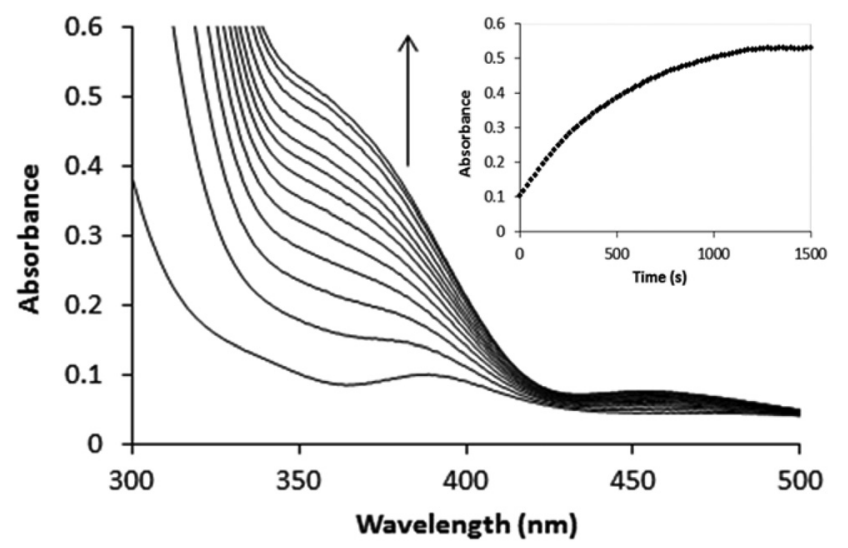

Fig. 2 Spectral changes recorded for the oxidation of $1 \mathrm{mM}\left[\mathrm{PtCl}_{4}\right]^{2-}$ by $100 \mathrm{mM} \mathrm{H}_{2} \mathrm{O}_{2}$ in $1 \mathrm{M} \mathrm{HCl}$.

Small differences in absorbance versus time plots collected at a specific wavelength were noticed when compared to spectra collected in the wavelength range $200-500 \mathrm{~nm}$ on a rapid-scan UV-Vis spectrophotometer. It has long been known that $\mathrm{Pt}(\mathrm{II} / \mathrm{Iv})$ complexes are sensitive to light resulting in photoinduced reactions. ${ }^{10,11}$ The rates of $\left[\mathrm{PtCl}_{4}\right]^{2-}$ and/or $\left[\mathrm{PtCl}_{6}\right]^{2-}$ aquation as well as $\left[\mathrm{PtCl}_{5}\left(\mathrm{H}_{2} \mathrm{O}\right)\right]^{-}$chloride anion reactions are enhanced when spectra are recorded in the $200-500 \mathrm{~nm}$ wavelength range, which accounts for the small differences observed in the kinetic traces. To suppress such effects, changes in absorbance were monitored at 262 or $353 \mathrm{~nm}$, close to the absorbance maxima of $\left[\mathrm{PtCl}_{6}\right]^{2-}$.

Oxidation of $\left[\mathrm{Pt}(\mathrm{CN})_{4}\right]^{2-}$ by chlorine yields trans-[Pt $(\mathrm{CN})_{4} \mathrm{Cl}-$ $\left.\left(\mathrm{H}_{2} \mathrm{O}\right)\right]^{-}$as the primary product even when the free chloride ion concentration in solution is as high as $1 \mathrm{M} .{ }^{9} \mathrm{~A}$ preference for solvent water to coordinate the negatively charged Pt(II) precursor complex, trans to the oxidant, was considered here. The spectrum of trans- $\left[\mathrm{PtCl}_{4}\left(\mathrm{H}_{2} \mathrm{O}\right)_{2}\right]$ is known and has been reported before. ${ }^{2}$ No evidence could be found for the presence of significant concentrations of trans $-\left[\mathrm{PtCl}_{4}\left(\mathrm{H}_{2} \mathrm{O}\right)_{2}\right]$ under the reaction conditions and in the time scale studied here. Associations between $\left[\mathrm{PtCl}_{4}\right]^{2-}$ and trans- $\left[\mathrm{PtCl}_{4}\left(\mathrm{H}_{2} \mathrm{O}\right)_{2}\right]$, rapidly resulting in the formation of $\left[\mathrm{PtCl}_{5}\left(\mathrm{H}_{2} \mathrm{O}\right)\right]^{-}$and/or $\left[\mathrm{PtCl}_{6}\right]^{2-}$ within the time scale investigated here, is possible as suggested by the rate constants estimated in this study (vide infra).

\section{Results}

\section{Oxidation of $\left[\mathrm{PtCl}_{4}\right]^{2-} \leq \mathbf{0 . 0 7} \mathrm{mM}$}

Oxidation of $\left[\mathrm{PtCl}_{4}\right]^{2-}$ by excess hydrogen peroxide quantitatively converts all $\mathrm{Pt}(\mathrm{II}) \rightarrow \mathrm{Pt}(\mathrm{Iv})$ so that $-\mathrm{d}\left[\mathrm{Pt}^{\mathrm{II}}\right] / \mathrm{d} t=\mathrm{d}[\mathrm{Pt}(\mathrm{Iv})] / \mathrm{d} t$. Oxidation reactions of $\left[\mathrm{PtCl}_{4}\right]^{2-} \leq 0.07 \mathrm{mM}$ with $\left[\mathrm{H}_{2} \mathrm{O}_{2}\right]$ $(5-100 \mathrm{mM})$ generate predominantly linear absorbance vs. time plots at $262 \mathrm{~nm}$ (Fig. 1; data summarized in Table 1), indicating that the reaction is pseudo-zero order with respect to $\mathrm{Pt}(\mathrm{II})$ and the observed rate is defined by rate law eqn (4).

$$
\mathrm{d}[\mathrm{Pt}(\mathrm{IV})] / \mathrm{d} t=k^{0}\left[\mathrm{H}_{2} \mathrm{O}_{2}\right]=k_{\text {obs }}^{0}\left(\mathrm{M} \mathrm{s}^{-1}\right)
$$

The observed rate constants $\left(k_{\mathrm{obs}}^{0}\right)$ were obtained directly from the slope of concentration versus time plots. Plots of $k_{\text {obs }}^{0}$ versus $\left[\mathrm{H}_{2} \mathrm{O}_{2}\right]$ are linear with zero intercept for the $\left[\mathrm{PtCl}_{4}\right]^{2-}$ concentration range 0.02-0.04 mM (ESI Fig. S1A $\dagger$ ). A small intercept $\sim 1.0 \times 10^{-8} \mathrm{M} \mathrm{s}^{-1}$ (ESI Fig. S1B $\dagger$ ) was observed for $\left[\mathrm{PtCl}_{4}\right]^{2-}$ concentrations between 0.05 and $0.07 \mathrm{mM}$. Pseudozero order rate constants $k^{0}\left(\mathrm{~s}^{-1}\right)$ calculated from eqn (5) are

Table 1 Experimental conditions and kinetic data for the oxidation of $0.02-0.07 \mathrm{mM}\left[\mathrm{PtCl}_{4}\right]^{2-}$ yielding pseudo-zero order kinetics at $35^{\circ} \mathrm{C}$

\begin{tabular}{|c|c|c|c|}
\hline $\begin{array}{l}{\left[\mathrm{PtCl}_{4}\right]^{2-}} \\
(\mathrm{mM})\end{array}$ & $\begin{array}{l}\mathrm{H}_{2} \mathrm{O}_{2} \\
(\mathrm{mM})\end{array}$ & $k_{\mathrm{obs}}^{0}\left(\mathrm{M} \mathrm{s}^{-1}\right)$ & $k_{0}=k_{\mathrm{obs}}^{0} /\left[\mathrm{H}_{2} \mathrm{O}_{2}\right]\left(\mathrm{s}^{-1}\right)$ \\
\hline 0.02 & 100 & $6.49 \times 10^{-8}$ & $6.49 \times 10^{-7}$ \\
\hline 0.02 & 70 & $4.64 \times 10^{-8}$ & $6.63 \times 10^{-7}$ \\
\hline 0.02 & 50 & $3.19 \times 10^{-8}$ & $6.38 \times 10^{-7}$ \\
\hline 0.02 & 30 & $1.97 \times 10^{-8}$ & $6.56 \times 10^{-7}$ \\
\hline 0.02 & 10 & $6.83 \times 10^{-8}$ & $6.83 \times 10^{-7}$ \\
\hline 0.02 & 5 & $3.67 \times 10^{-8}$ & $7.34 \times 10^{-7}$ \\
\hline 0.03 & 100 & $5.49 \times 10^{-8}$ & $5.49 \times 10^{-7}$ \\
\hline 0.03 & 70 & $3.84 \times 10^{-8}$ & $5.49 \times 10^{-7}$ \\
\hline 0.03 & 50 & $2.89 \times 10^{-8}$ & $5.78 \times 10^{-7}$ \\
\hline 0.03 & 30 & $1.68 \times 10^{-8}$ & $5.60 \times 10^{-7}$ \\
\hline 0.03 & 10 & $0.67 \times 10^{-8}$ & $6.74 \times 10^{-7}$ \\
\hline 0.03 & 5 & $0.39 \times 10^{-8}$ & $7.74 \times 10^{-7}$ \\
\hline 0.04 & 100 & $6.68 \times 10^{-8}$ & $6.68 \times 10^{-7}$ \\
\hline 0.04 & 70 & $4.86 \times 10^{-8}$ & $6.94 \times 10^{-7}$ \\
\hline 0.04 & 50 & $3.34 \times 10^{-8}$ & $6.68 \times 10^{-7}$ \\
\hline 0.04 & 30 & $2.06 \times 10^{-8}$ & $6.87 \times 10^{-7}$ \\
\hline 0.04 & 10 & $0.85 \times 10^{-8}$ & $8.52 \times 10^{-7}$ \\
\hline 0.04 & 5 & $0.46 \times 10^{-8}$ & $9.12 \times 10^{-7}$ \\
\hline 0.05 & 100 & $7.96 \times 10^{-8}$ & $7.96 \times 10^{-7}$ \\
\hline 0.05 & 70 & $6.54 \times 10^{-8}$ & $9.34 \times 10^{-7}$ \\
\hline 0.05 & 60 & $5.51 \times 10^{-8}$ & $9.18 \times 10^{-7}$ \\
\hline 0.05 & 50 & $4.52 \times 10^{-8}$ & $9.04 \times 10^{-7}$ \\
\hline 0.05 & 40 & $3.82 \times 10^{-8}$ & $9.55 \times 10^{-7}$ \\
\hline 0.06 & 100 & $8.69 \times 10^{-8}$ & $8.69 \times 10^{-7}$ \\
\hline 0.06 & 70 & $6.58 \times 10^{-8}$ & $9.4 \times 10^{-7}$ \\
\hline 0.06 & 60 & $5.83 \times 10^{-8}$ & $9.72 \times 10^{-7}$ \\
\hline 0.06 & 50 & $4.96 \times 10^{-8}$ & $9.92 \times 10^{-7}$ \\
\hline 0.06 & 40 & $4.27 \times 10^{-8}$ & $10.68 \times 10^{-7}$ \\
\hline 0.07 & 100 & $8.75 \times 10^{-8}$ & $8.75 \times 10^{-7}$ \\
\hline 0.07 & 70 & $6.47 \times 10^{-8}$ & $9.24 \times 10^{-7}$ \\
\hline 0.07 & 60 & $6.14 \times 10^{-8}$ & $10.23 \times 10^{-7}$ \\
\hline 0.07 & 50 & $4.85 \times 10^{-8}$ & $9.70 \times 10^{-7}$ \\
\hline \multirow[t]{2}{*}{0.07} & 40 & $4.45 \times 10^{-8}$ & $11.13 \times 10^{-7}$ \\
\hline & & \multicolumn{2}{|c|}{ Mean value $=(8 \pm 2) \times 10^{-7} \mathrm{~s}^{-1}$} \\
\hline
\end{tabular}


Table 2 Kinetic data for the oxidation of $\left[\mathrm{PtCl}_{4}\right]^{2-}$ by $\mathrm{H}_{2} \mathrm{O}_{2}$ as a function of temperature with calculated activation parameters

\begin{tabular}{llllll}
\hline $\begin{array}{l}{\left[\mathrm{PtCl}_{4}\right]^{2-}} \\
(\mathrm{mM})\end{array}$ & $\begin{array}{l}{\left[\mathrm{H}_{2} \mathrm{O}_{2}\right]} \\
(\mathrm{mM})\end{array}$ & $\begin{array}{l}\text { Temp. } \\
\left({ }^{\circ} \mathrm{C}\right)\end{array}$ & $k^{0}\left(\mathrm{~s}^{-1}\right)$ & $\begin{array}{l}\Delta H^{*} \\
\left(\mathrm{~kJ} \mathrm{~mol}^{-1}\right)\end{array}$ & $\begin{array}{l}\Delta S^{*} \\
\left(\mathrm{~J} \mathrm{~K}^{-1} \mathrm{~mol}^{-1}\right)\end{array}$ \\
\hline 0.04 & 100 & 15 & $0.76 \times 10^{-7}$ & $78 \pm 5$ & $-109 \pm 7$ \\
0.04 & 100 & 20 & $1.53 \times 10^{-7}$ & & \\
0.04 & 100 & 25 & $2.75 \times 10^{-7}$ & & \\
0.04 & 100 & 30 & $4.57 \times 10^{-7}$ & & \\
0.04 & 100 & 35 & $6.68 \times 10^{-7}$ & & \\
\hline & & & $k_{\mathrm{H}_{2} \mathrm{O}_{2}}$ & & \\
& & & $\left(\mathrm{M}^{-1} \mathrm{~s}^{-1}\right)$ & & \\
& & & & \\
1 & 300 & 15 & $3.18 \times 10^{-3}$ & $52 \pm 1$ & \\
1 & 300 & 20 & $4.43 \times 10^{-3}$ & & \\
1 & 300 & 25 & $6.81 \times 10^{-3}$ & & \\
1 & 300 & 30 & $9.57 \times 10^{-3}$ & & \\
1 & 300 & 35 & $13.83 \times 10^{-3}$ & &
\end{tabular}

listed in Table 1, from which it follows that $k^{0}=(8 \pm 2) \times$ $10^{-7} \mathrm{~s}^{-1}$ over the entire concentration range investigated.

$$
k^{0}=k_{\mathrm{obs}}^{0}\left[\mathrm{H}_{2} \mathrm{O}_{2}\right]^{-1}
$$

The activation parameters $\Delta H^{\ddagger}$ and $\Delta S^{\ddagger}$ were estimated from the variation of $k_{\mathrm{obs}}^{0}$ in the temperature range $15-35{ }^{\circ} \mathrm{C}$ (Table 2), and plots of $\ln \left(k^{0} / T\right)$ versus $1 / T$ according to the Eyring equation gave linear correlations (ESI Fig. S2 $\dagger$ ). Values for $\Delta H^{*}$ and $\Delta S^{\ddagger}$ were subsequently calculated from the slope and intercept of such plots according to eqn (6) and (7), where $k_{\mathrm{B}}$ is Boltzmann's constant and $h$ is Planck's constant. The calculated parameters are listed in Table 2.

$$
\begin{gathered}
\text { Slope }=-\Delta H^{\ddagger} / R \\
\text { Intercept }=\ln \left(k_{\mathrm{B}} / h\right)+\Delta S^{\ddagger} / R
\end{gathered}
$$

The activation volume of the oxidation reaction $\left(\Delta V^{\ddagger}\right)$ for the zero-order process was estimated by varying the pressure in the range $10-132 \mathrm{MPa}$. A plot of $\ln k^{0}$ versus pressure is linear (Fig. S3, ESI $\dagger$ ) and $\Delta V^{*}$ was obtained from the slope of the plot according to eqn (8). The calculated activation parameters are included in Table 3.

Table 3 Kinetic data for the oxidation of $\left[\mathrm{PtCl}_{4}\right]^{2-}$ by $\mathrm{H}_{2} \mathrm{O}_{2}$ as a function of pressure with calculated activation volumes at $35^{\circ} \mathrm{C}$

\begin{tabular}{lllll}
\hline $\left.\begin{array}{l}{[\mathrm{PtCl}} \\
(\mathrm{mM})\end{array}\right]^{2-}$ & $\begin{array}{l}{\left[\mathrm{H}_{2} \mathrm{O}_{2}\right]} \\
(\mathrm{mM})\end{array}$ & $\begin{array}{l}\text { Pressure } \\
(\mathrm{MPa})\end{array}$ & $k^{0}\left(\mathrm{~s}^{-1}\right)$ & $\begin{array}{l}\Delta V^{*} \\
\left(\mathrm{~cm}^{3} \mathrm{~mol}^{-1}\right)\end{array}$ \\
\hline 0.04 & 100 & 10 & $1.38 \times 10^{-6}$ & $-8 \pm 2$ \\
0.04 & 100 & 51 & $1.59 \times 10^{-6}$ & \\
0.04 & 100 & 91 & $1.79 \times 10^{-6}$ & \\
0.04 & 100 & 132 & $2.02 \times 10^{-6}$ & \\
\hline & & & $k_{\mathrm{H}_{2} \mathrm{O}_{2}}\left(\mathrm{M}^{-1} \mathrm{~s}^{-1}\right)$ & \\
& & & & \\
1 & 15 & 5 & $1.67 \times 10^{-2}$ & $-7.8 \pm 0.4$ \\
1 & 15 & 51 & $1.86 \times 10^{-2}$ & \\
1 & 15 & 101 & $2.23 \times 10^{-2}$ & \\
1 & 15 & 152 & $2.58 \times 10^{-2}$ &
\end{tabular}

$$
\left[\mathrm{d}\left(\ln \mathrm{k}^{0}\right) / \mathrm{d} P\right]_{\mathrm{T}}=-\Delta V^{\ddagger} / R T
$$

\section{Oxidation of $\left[\mathrm{PtCl}_{4}\right]^{2-} \geq 0.2 \mathrm{mM}$}

Oxidation of $\left[\mathrm{PtCl}_{4}\right]^{2-}$ at concentration levels $\geq 0.2 \mathrm{mM}$ by $\left[\mathrm{H}_{2} \mathrm{O}_{2}\right]$ in the concentration range $15-300 \mathrm{mM}$ resulted in absorbance $v s$. time traces at $353 \mathrm{~nm}$ which exhibited firstorder character. These kinetic traces show inflection points once equilibrium is reached (ESI Fig. S4 $\dagger$ ), reminiscent of zeroorder kinetics prevailing at relative low concentrations of $\left[\mathrm{PtCl}_{4}\right]^{2-}$. The observed rate constants $\left(k_{\text {obs }}\right)$ were estimated from the second-order rate law eqn (9) and are listed in Table 4. Only absorbance data points prior to the inflection point were used for the estimation of $k_{\mathrm{obs}}$ values, as obtained from least-squares fits.

$$
\mathrm{d}[\mathrm{Pt}(\mathrm{IV})] / \mathrm{d} t=k_{\mathrm{H}_{2} \mathrm{O}_{2}}[\mathrm{Pt}(\mathrm{II})]\left[\mathrm{H}_{2} \mathrm{O}_{2}\right]
$$

Plots of $k_{\mathrm{obs}}$ versus $\left[\mathrm{H}_{2} \mathrm{O}_{2}\right]$ demonstrate a linear dependence (ESI Fig. S5†), suggesting that the reaction is first order with respect to hydrogen peroxide. The second order rate constants $k_{\mathrm{H}_{2} \mathrm{O}_{2}}$ were calculated from eqn (10) to give the average value $(1.5 \pm 0.1) \times 10^{-2} \mathrm{M}^{-1} \mathrm{~s}^{-1}$.

$$
k_{\mathrm{H}_{2} \mathrm{O}_{2}}=k_{\mathrm{obs}}\left[\mathrm{H}_{2} \mathrm{O}_{2}\right]^{-1}
$$

Oxidation of $1 \mathrm{mM}\left[\mathrm{PtCl}_{4}\right]^{2-}$ with $300 \mathrm{mM} \mathrm{H}_{2} \mathrm{O}_{2}$ generated traces illustrating pseudo-first order character. Activation parameters were estimated under these reaction conditions from the variation of $k_{\mathrm{H}_{2} \mathrm{O}_{2}}$ in the temperature range $15-35{ }^{\circ} \mathrm{C}$ and eqn (6) and (7) (Table 2). Values of $\Delta V^{*}$ were estimated by varying the pressure between 5 and $152 \mathrm{MPa}$ for the oxidation of $1 \mathrm{mM}\left[\mathrm{PtCl}_{4}\right]^{2-}$ with $15 \mathrm{mM} \mathrm{H} \mathrm{H}_{2} \mathrm{O}_{2}$. A plot of $\ln k_{\mathrm{H}_{2} \mathrm{O}_{2}}$ versus pressure is linear (Fig. S6, ESI $\dagger$ ) and allowed the estimation of $\Delta V^{\star}$ from eqn (8) listed in Table 3.

\section{Effect of acid and chloride concentrations on the oxidation rate and reaction order}

The effect of variation of acid and/or chloride concentration on the reaction rate and order was evaluated in the ranges 0.6-1 $\mathrm{M}$ and $0.02-1 \mathrm{M}$, respectively. Concentrations of $\mathrm{Pt}$ (II)

Table 4 Experimental conditions and kinetic data for the oxidation of $0.2-1.0 \mathrm{mM}\left[\mathrm{PtCl}_{4}\right]^{2-}$ yielding pseudo-first order kinetics at $35^{\circ} \mathrm{C}$

\begin{tabular}{lcll}
\hline $\begin{array}{l}\left.\mathrm{PtCl}_{4}\right]^{2-} \\
(\mathrm{mM})\end{array}$ & $\begin{array}{c}{\left[\mathrm{H}_{2} \mathrm{O}_{2}\right]} \\
(\mathrm{mM})\end{array}$ & $k_{\text {obs }}\left(\mathrm{s}^{-1}\right)$ & $\begin{array}{l}k_{\mathrm{H}_{2} \mathrm{O}_{2}}=k_{\text {obs }} /\left[\mathrm{H}_{2} \mathrm{O}_{2}\right] \\
\left(\mathrm{M}^{-1} \mathrm{~s}^{-1}\right)\end{array}$ \\
\hline 1.0 & 300 & $3.94 \times 10^{-3}$ & $1.31 \times 10^{-2}$ \\
1.0 & 100 & $1.52 \times 10^{-3}$ & $1.52 \times 10^{-2}$ \\
1.0 & 50 & $0.81 \times 10^{-3}$ & $1.62 \times 10^{-2}$ \\
1.0 & 15 & $0.30 \times 10^{-3}$ & $2.00 \times 10^{-2}$ \\
0.6 & 300 & $4.49 \times 10^{-3}$ & $1.50 \times 10^{-2}$ \\
0.6 & 100 & $1.57 \times 10^{-3}$ & $1.57 \times 10^{-2}$ \\
0.6 & 50 & $0.78 \times 10^{-3}$ & $1.56 \times 10^{-2}$ \\
0.6 & 15 & $0.23 \times 10^{-3}$ & $1.53 \times 10^{-2}$ \\
0.2 & 300 & $3.84 \times 10^{-3}$ & $1.28 \times 10^{-2}$ \\
0.2 & 100 & $1.27 \times 10^{-3}$ & $1.27 \times 10^{-2}$ \\
0.2 & 50 & $0.74 \times 10^{-3}$ & $1.48 \times 10^{-2}$ \\
0.2 & 15 & $0.23 \times 10^{-3}$ & $1.53 \times 10^{-2}$ \\
& & Mean value $=(1.5 \pm 0.1) \times 10^{-2} \mathrm{M}^{-1} \mathrm{~s}^{-1}$
\end{tabular}


Table 5 Oxidation of $\left[\mathrm{PtCl}_{4}\right]^{2-}$ performed to determine the effect of chloride and acid concentrations on the observed reaction order at $35^{\circ} \mathrm{C}$

\begin{tabular}{lllll}
\hline $\mathrm{HCl}(\mathrm{M})$ & $\mathrm{HClO}_{4}(\mathrm{M})$ & $\mathrm{NaClO}_{4}(\mathrm{M})$ & $k_{\text {obs }}^{0}\left(\mathrm{M} \mathrm{s}^{-1}\right)$ & $k^{0}=k_{\mathrm{obs}}^{0} /\left[\mathrm{H}_{2} \mathrm{O}_{2}\right]\left(\mathrm{s}^{-1}\right)$ \\
\hline 0.5 & 0.5 & - & $7.71 \times 10^{-7}$ & $9.64 \times 10^{-6}$ \\
0.5 & 0.3 & 0.2 & $5.92 \times 10^{-7}$ & $7.40 \times 10^{-6}$ \\
0.5 & 0.1 & 0.4 & $4.27 \times 10^{-7}$ & $5.34 \times 10^{-6}$ \\
1 & 0 & - & $1.02 \times 10^{-7}$ & $1.28 \times 10^{-6}$ \\
0.6 & 0.4 & - & $7.07 \times 10^{-8}$ & $8.84 \times 10^{-7}$ \\
0.2 & 0.8 & - & $3.65 \times 10^{-8}$ & $4.56 \times 10^{-7}$ \\
0.02 & 0.98 & - & $2.17 \times 10^{-8}$ & $2.71 \times 10^{-7}$ \\
& & & &
\end{tabular}

and hydrogen peroxide were kept constant at $0.04 \mathrm{mM}$ and $80 \mathrm{mM}$, respectively. For the high end concentration range, zero-order kinetics predominated (ESI Fig. S7, ESI, $\uparrow$ for the variation of $\left[\mathrm{Cl}^{-}\right]$), while a gradual change to first-order kinetics was observed for sufficiently low concentrations of $\left[\mathrm{H}^{+}\right]$ and/or $\left[\mathrm{Cl}^{-}\right]$. Rate constants $\left(k_{\mathrm{obs}}^{0}\right)$ were estimated from the slope of concentration versus time plots. Traces that display a degree of first-order character were evaluated for the first $500 \mathrm{~s}$ (Fig. S7, $\dagger$ plots 3 and 4). The values for $k_{\mathrm{obs}}^{0}$, obtained in this manner, are listed in Table 5. Plots of $k_{\mathrm{obs}}^{0}$ versus $\left[\mathrm{H}^{+}\right]$and $k_{\mathrm{obs}}^{0}$ versus $\left[\mathrm{Cl}^{-}\right]$are linear $\left(R^{2}>0.99\right)$ with a small intercept in both cases (Fig. S8, ESI, $\dagger-3.4 \times 10^{-7} \mathrm{M} \mathrm{s}^{-1}$ and $20.3 \times 10^{-7} \mathrm{M} \mathrm{s}^{-1}$, respectively), suggesting that $k_{\mathrm{obs}}^{0}$ varies with $\left[\mathrm{H}^{+}\right]$and $\left[\mathrm{Cl}^{-}\right]$ according to eqn (11):

$$
k_{\mathrm{obs}}^{0}=a+b[\mathrm{Q}]
$$

where Q represents $\left[\mathrm{H}^{+}\right]$or $\left[\mathrm{Cl}^{-}\right], a=3.4 \times 10^{-7} \mathrm{M} \mathrm{s}^{-1} / 20.3 \times$ $10^{-7} \mathrm{M} \mathrm{s}^{-1}$ and $b=8.6 \times 10^{-7} \mathrm{~s}^{-1} / 82.3 \times 10^{-7} \mathrm{~s}^{-1}$, respectively. These values were obtained directly from the intercept and gradient of the plots in Fig. S8. $\dagger$

\section{Discussion}

\section{Rate law for hypochlorous acid formation}

An oxidation mechanism for $\left[\mathrm{PtCl}_{4}\right]^{2-}$ displaying zero-order kinetics can be envisaged as a result of the rapid formation of hypochlorous acid according to eqn (2). Catalytic decomposition of hydrogen peroxide in hydrochloric acid has been studied in detail. It was concluded that hydrogen peroxide decomposes via the acid-dependent reaction eqn (2), in addition to an acid-independent pathway eqn (12). ${ }^{17-19}$

$$
\mathrm{H}_{2} \mathrm{O}_{2}+\mathrm{Cl}^{-} \rightarrow \mathrm{H}_{2} \mathrm{O}+\mathrm{ClO}^{-}
$$

The general rate law eqn (13) was established to define the overall rate of decomposition via the parallel reactions eqn (2) and (12).

$$
-\mathrm{d}\left[\mathrm{H}_{2} \mathrm{O}_{2}\right] / \mathrm{d} t=k_{1}\left[\mathrm{H}_{2} \mathrm{O}_{2}\right]\left[\mathrm{Cl}^{-}\right]\left[\mathrm{H}^{+}\right]+k_{1}^{0}\left[\mathrm{H}_{2} \mathrm{O}_{2}\right]\left[\mathrm{Cl}^{-}\right]
$$

Reaction (12) is slow relative to the acid-dependent decomposition of hydrogen peroxide, reaction (2), especially in an acidic matrix which will enhance the acid-dependent reaction. The second term in eqn (13) becomes negligible in $1 \mathrm{M}$
$\mathrm{H}^{+}$, as used in this study, so that the rate law for decomposition of hydrogen peroxide reduces to eqn (14).

$$
-\mathrm{d}\left[\mathrm{H}_{2} \mathrm{O}_{2}\right] / \mathrm{d} t=k_{1}\left[\mathrm{H}_{2} \mathrm{O}_{2}\right]\left[\mathrm{Cl}^{-}\right]\left[\mathrm{H}^{+}\right]
$$

\section{Zero-order reaction mechanism}

If a $\left[\mathrm{PtCl}_{4}\right]^{2-}$ solution is mixed with excess hydrogen peroxide and hydrochloric acid, hydrogen peroxide is consumed via reactions denoted by $k_{\mathrm{H}_{2} \mathrm{O}_{2}}$ and $k_{\mathrm{HOCl}}$ in the scheme outlined in eqn (3). Since oxidation of $\left[\mathrm{PtCl}_{4}\right]^{2-}$ with hypochlorous acid is rapid, the $k_{1}$ reaction is expected to be the major oxidation reaction under the condition of eqn (15). ${ }^{9,19}$

$$
k_{\mathrm{H}_{2} \mathrm{O}_{2}}\left[\mathrm{PtCl}_{4}{ }^{2-}\right] \ll k_{1}\left[\mathrm{Cl}^{-}\right]\left[\mathrm{H}^{+}\right]
$$

The condition is fulfilled where $\left[\mathrm{PtCl}_{4}\right]^{2-} \ll 0.5 \mathrm{mM}$ for $\left[\mathrm{Cl}^{-}\right]=\left[\mathrm{H}^{+}\right]=1 \mathrm{M} . \dagger$ Under such conditions hydrogen peroxide will disappear via the consecutive reactions $k_{1} \rightarrow k_{\mathrm{HOCl}}$ depicted in the scheme in (3), where $k_{1}$ is the rate-determining reaction for the conditions of eqn (16).

$$
k_{\mathrm{HOCl}}\left[\mathrm{PtCl}_{4}{ }^{2-}\right] \gg k_{1}\left[\mathrm{Cl}^{-}\right]\left[\mathrm{H}^{+}\right]
$$

Eqn (16) is fulfilled if $\left[\mathrm{PtCl}_{4}\right]^{2-} \gg 4.6 \times 10^{-9} \mathrm{mM}$. Hence, oxidation proceeds mainly via hypochlorous acid formation in the concentration range $4.6 \times 10^{-9} \mathrm{mM} \ll\left[\mathrm{PtCl}_{4}\right]^{2-} \ll 0.5 \mathrm{mM}$, with $\left[\mathrm{Cl}^{-}\right]=\left[\mathrm{H}^{+}\right]=1 \mathrm{M}$. Oxidation via hydrogen peroxide under these conditions becomes negligibly slow, and the conversion of $\mathrm{H}_{2} \mathrm{O}_{2} \rightarrow \mathrm{HOCl}$ is the rate-determining step. Under such conditions the reaction appears to be pseudo-zero-order with respect to $\left[\mathrm{PtCl}_{4}\right]^{2-}$. The rate of hypochlorous acid formation $\left(k_{1}\right)$ in the hydrogen peroxide concentration range 5-100 mM varies from $1.04 \times 10^{-8}$ to $2.07 \times 10^{-7} \mathrm{M} \mathrm{s}^{-1}$ according to eqn (14). These values are in the same range as values of $k^{0}$ determined for the oxidation of $\left[\mathrm{PtCl}_{4}\right]^{2-}$ reported in Table 1 .

\section{First-order reaction mechanism}

If the concentration range of $\left[\mathrm{PtCl}_{4}\right]^{2-}>0.5 \mathrm{mM}$, with $\left[\mathrm{Cl}^{-}\right]=$ $\left[\mathrm{H}^{+}\right]=1 \mathrm{M}$, oxidation of $\left[\mathrm{PtCl}_{4}\right]^{2-}$ by hydrogen peroxide becomes dominant and the rate of hypochlorous acid formation is small by comparison. Under such reaction conditions, oxidation via the consecutive reactions $k_{1} \rightarrow k_{\mathrm{HOCl}}$ competes for the oxidation of $\left[\mathrm{PtCl}_{4}\right]^{2-}$ with reaction $k_{\mathrm{H}_{2} \mathrm{O}_{2}}$ depicted in the scheme given in eqn (3). In the absence of free chloride ions, oxidation of $\left[\mathrm{PtCl}_{4}\right]^{2-}$ by hydrogen peroxide is first-order with respect to both $\left[\mathrm{PtCl}_{4}\right]^{2-}$ and $\mathrm{H}_{2} \mathrm{O}_{2}$ according to the rate law in eqn (9). ${ }^{8}$ The "curvature" observed in kinetic traces for oxidation of $\left[\mathrm{PtCl}_{4}\right]^{2-} \geq 0.2 \mathrm{mM}$ (Fig. 2) thus illustrates this parallel pseudo-first-order oxidation mechanism by hydrogen peroxide. The calculated $k_{\text {obs }}$ values according to eqn (9) for the hydrogen peroxide concentration range $15-300 \mathrm{mM}$ vary between $6.38 \times 10^{-5}$ and $1.28 \times 10^{-3} \mathrm{M} \mathrm{s}^{-1}$. The experimentally determined $k_{\text {obs }}$ values for oxidation of $\left[\mathrm{PtCl}_{4}{ }^{2-}\right] \geq 0.2 \mathrm{mM}$ in

$\ddagger$ Calculated from eqn (15) with $k_{\mathrm{H}_{2} \mathrm{O}_{2}}=4.25 \times 10^{-3} \mathrm{M}^{-1} \mathrm{~s}^{-1}$ and $k_{1}=2.07 \times 10^{-6}$ $\mathrm{M}^{-2} \mathrm{~s}^{-1} \cdot 8,18$

$\S$ Calculated from eqn (16) with $k_{\mathrm{HOCl}}=(4.5 \pm 0.5) \times 10^{5} \mathrm{M}^{-1} \mathrm{~s}^{-1} \cdot 9$ 
this work as listed in Table 4 are at the upper limit of this range. A deviation between expected and calculated values may be reasonable, since estimation of $k_{\text {obs }}$ values from rate law eqn (9) does not account for any oxidation by hypochlorous acid, the parallel reaction under these reaction conditions.

\section{Rate dependence on chloride and acid concentrations}

The oxidation rate and order of $\left[\mathrm{PtCl}_{4}\right]^{2-}$ is directly proportional to both chloride and acid concentrations as illustrated by the $k_{\mathrm{obs}}$ values shown in Table 5 . Under conditions where $\left[\mathrm{Cl}^{-}\right]\left[\mathrm{H}^{+}\right] \gg 0.082 \mathrm{M}^{2}$ for concentrations of $\left[\mathrm{PtCl}_{4}\right]^{2-}=$ $0.04 \mathrm{mM}$ and $\left[\mathrm{H}_{2} \mathrm{O}_{2}\right]=80 \mathrm{mM}$, the condition of eqn (15) will be valid.t On the other hand, if $\left[\mathrm{Cl}^{-}\right]\left[\mathrm{H}^{+}\right] \ll 0.082 \mathrm{M}^{2}$, the firstorder mechanism becomes dominant resulting in more prominent "curvature" in the kinetic trace 4 as indicated in Fig. S7, ESI. $\dagger$

Under these conditions, oxidation is first-order with respect to both $\left[\mathrm{Cl}^{-}\right]$and $\left[\mathrm{H}^{+}\right]$as suggested by the linear dependence of $k_{\mathrm{obs}}^{0}$ on $\left[\mathrm{Cl}^{-}\right]$and $\left[\mathrm{H}^{+}\right]$(Fig. S8, ESI $\dagger$ ). In order to keep the rate law consistent for the range of reaction conditions investigated, values of $k_{\mathrm{obs}}^{0}$ were obtained directly from concentration versus time plots. This approach does not account for the parallel first-order oxidation reaction, a possible consequence of the small intercept in these graphs. The overall rate law accounting for both reaction pathways is expressed by eqn (17), and is the sum of eqn (4) and (9).

$$
\mathrm{d}[\mathrm{Pt}(\mathrm{IV})] / \mathrm{d} t=\left(k^{0}+k_{\mathrm{H}_{2} \mathrm{O}_{2}}[\mathrm{Pt}(\mathrm{II})]\right)\left[\mathrm{H}_{2} \mathrm{O}_{2}\right]
$$

\section{Chlorine as an oxidant}

Several attempts to determine a rate constant for the oxidation of $\left[\mathrm{PtCl}_{4}\right]^{2-}$ by chlorine have failed. ${ }^{9,20,21}$ Nevertheless, the rapid oxidation of Pt(II) complexes by chlorine is well established. Oxidation of $\left[\mathrm{Pt}(\mathrm{CN})_{4}\right]^{2-}$ by chlorine for instance exceeds the oxidation rate of $\left[\mathrm{Pt}(\mathrm{CN})_{4}\right]^{2-}$ by hypochlorous acid by five orders of magnitude. ${ }^{9}$ Hypochlorous acid and chlorine are in rapid equilibrium in aqueous solution according to eqn (18).

$$
\mathrm{HOCl}+\mathrm{H}^{+}+\mathrm{Cl}^{-} \underset{k_{-2}}{\stackrel{k_{2}}{\rightleftharpoons}} \mathrm{Cl}_{2}+\mathrm{H}_{2} \mathrm{O}
$$

Equilibrium (18) has been responsible for some of the confusion in the literature, where apparent oxidation by chlorine was in fact oxidation by hypochlorous acid. ${ }^{9,20,21}$ If the formation of chlorine as a result of eqn (18) and subsequent oxidation of $\left[\mathrm{PtCl}_{4}\right]^{2-}$ exceeds the rate of formation and oxidation by hypochlorous acid as defined by eqn (19), the overall oxidation reaction will proceed via consecutive reactions depicted by $k_{1} \rightarrow k_{2} \rightarrow k_{\mathrm{Cl} 2}$ in the scheme given in eqn (3) and chlorine must be considered as an oxidant in the mechanism discussed here.

$$
k_{\mathrm{HOCl}}\left[\mathrm{PtCl}_{4}{ }^{2-}\right] \ll k_{2}\left[\mathrm{H}^{+}\right]\left[\mathrm{Cl}^{-}\right]
$$

Chlorine is the dominant species present in hypochlorous acid/chlorine solutions at equilibrium ( $\left.>99.9 \%, \mathrm{Cl}_{2}=1 \mathrm{mM}\right)$. However, since $\left[\mathrm{PtCl}_{4}\right]^{2-}$ is present in large excess relative to the catalytic concentrations of hypochlorous acid formed by eqn (2), chlorine hydrolysis via $k_{-2}$ according to eqn (19) will be negligibly slow by comparison. The value of $k_{2}$ is given as $2.66 \times 10^{4} \mathrm{M}^{-2} \mathrm{~s}^{-1}$ in the literature. ${ }^{9}$ Substituting this value into eqn (19) gives the condition that $[\mathrm{Pt}(\mathrm{II})] \ll 60 \mathrm{mM}$ when $\left[\mathrm{H}^{+}\right]$and $\left[\mathrm{Cl}^{-}\right]$are $1 \mathrm{M}$. This is the case in our solutions where $[\mathrm{Pt}(\mathrm{II})]=1-20 \mathrm{mM}$, and implies that $\mathrm{Cl}_{2}$ must be considered as an oxidant here if we assume that $k_{\mathrm{Cl} 2} \geq k_{\mathrm{H}_{2} \mathrm{O}_{2}}$, which is not unreasonable. Oxidation of $\left[\mathrm{PtCl}_{4}\right]^{2-}$ by chlorine will favour formation of $\left[\mathrm{PtCl}_{6}\right]^{2-}$ as opposed to the formation of $\left[\mathrm{PtCl}_{5}\left(\mathrm{H}_{2} \mathrm{O}\right)\right]^{-}$when hypochlorous acid is the major oxidant. Since the $\left[\mathrm{PtCl}_{5}\left(\mathrm{H}_{2} \mathrm{O}\right)\right]^{-} /\left[\mathrm{PtCl}_{6}\right]^{2-}$ ratio increases under conditions that favour the pseudo-zero order mechanism, it supports the idea that hypochlorous acid is the major oxidant and not chlorine.

\section{Conclusions and final comments}

The mechanism of oxidation of aqueous $\left[\mathrm{PtCl}_{4}\right]^{2-}$ by $\mathrm{H}_{2} \mathrm{O}_{2}$ in the presence of excess hydrochloric acid is remarkably complex. Our results obtained show that oxidation takes place at least via two parallel reactions with hypochlorous acid and hydrogen peroxide. The overall rate law $\mathrm{d}[\mathrm{Pt}(\mathrm{Iv})] / \mathrm{d} t=\left(k^{0}+\right.$ $\left.k_{\mathrm{H}_{2} \mathrm{O}_{2}}[\mathrm{Pt}(\mathrm{II})]\right)\left[\mathrm{H}_{2} \mathrm{O}_{2}\right]$ accounts for this process. For oxidation of $\left[\mathrm{PtCl}_{4}\right]^{2-}$ at relatively low concentrations, $\left[\mathrm{PtCl}_{4}\right]^{2-} \ll 0.5 \mathrm{mM}$, hypochlorous acid formation is faster relative to oxidation of $\left[\mathrm{PtCl}_{4}\right]^{2-}$ by hydrogen peroxide, as a result of the rate determining reaction $\mathrm{H}_{2} \mathrm{O}_{2}+\mathrm{H}^{+}+\mathrm{Cl}^{-} \rightarrow \mathrm{HOCl}+\mathrm{H}_{2} \mathrm{O}$, such that the rate law $\mathrm{d}[\mathrm{Pt}(\mathrm{Iv})] / \mathrm{d} t=k^{0}\left[\mathrm{H}_{2} \mathrm{O}_{2}\right]$ gives the value $k_{1}=(8 \pm 2) \times 10^{-7} \mathrm{~s}^{-1}$ at $35{ }^{\circ} \mathrm{C}$. For oxidation of $\left[\mathrm{PtCl}_{4}\right]^{2-} \gg 0.5 \mathrm{mM}$, oxidation by hydrogen peroxide becomes dominant resulting in a pseudofirst order rate law $\mathrm{d}[\mathrm{Pt}(\mathrm{Iv})] / \mathrm{d} t=k_{\mathrm{H}_{2} \mathrm{O}_{2}}[\mathrm{Pt}(\mathrm{II})]\left[\mathrm{H}_{2} \mathrm{O}_{2}\right]$, which results in values $k_{\mathrm{H}_{2} \mathrm{O}_{2}}=(1.5 \pm 0.1) \times 10^{-2} \mathrm{M}^{-1} \mathrm{~s}^{-1}$ at $35^{\circ} \mathrm{C}$.

The $\Delta H^{\ddagger}$ and $\Delta S^{\ddagger}$ values support bond formation prior to electron transfer for oxidation by both $\mathrm{H}_{2} \mathrm{O}_{2}$ and $\mathrm{HOCl}$ (Table 2). These values are comparable to values reported for the oxidation of $\left[\mathrm{PtCl}_{4}\right]^{2-}$ by $\mathrm{H}_{2} \mathrm{O}_{2}$ in $1 \mathrm{M} \mathrm{HClO}_{4}$ (viz. $\Delta H^{\ddagger}=$ $76 \pm 3 \mathrm{~kJ} \mathrm{~mol}^{-1}$ and $\Delta S^{\ddagger}=-35 \pm 9 \mathrm{~J} \mathrm{~K}^{-1} \mathrm{~mol}^{-1}$ ) pointing toward a similar mechanism. ${ }^{8}$ Activation volumes estimated here for the first-order and zero-order mechanisms are almost identical (Table 3 ). The negative $\Delta V^{*}$ values are characteristic of oxidative addition reactions, i.e. $\mathrm{H}_{2} \mathrm{O}_{2}-\mathrm{Pt}$ and/or $\mathrm{HOCl}-\mathrm{Pt}$ bond formation prior to electron transfer, indicating that oxidation takes place via a similar mechanism for both oxidants. ${ }^{22}$ These observations are in line with an inner-sphere one-step two-electron transfer mechanism typical of Pt(II) square planar complexes. Since square-planar Pt(II) complexes have a vacant coordination site in the axial plane, formation of an innersphere complex prior to electron transfer seems reasonable.

\section{Acknowledgements}

We thank the Deutscher Akademischer Austauschdienst (DAAD) for financial support to PM to perform this work at the University of Erlangen-Nürnberg. Financial assistance from 
Stellenbosch University and Anglo American Platinum Limited (bursary support to PM) is gratefully acknowledged.

\section{References}

1 B. Rosenberg, L. Van Camp and T. Krigas, Nature, 1965, 205, 698-699.

2 L. E. Cox, D. G. Peters and E. L. Wehry, J. Inorg. Nucl. Chem., 1972, 34, 297-305.

3 S. O. Dunham, R. D. Larsen and E. H. Abbott, Inorg. Chem., 1993, 32, 2049-2055.

4 L. I. Elding and L. Gustafson, Inorg. Chim. Acta, 1976, 19, 31-38.

5 P. Murray and K. R. Koch, J. Coord. Chem., 2010, 63, 25612577.

6 F. Basolo, P. H. Wilks, R. G. Pearson and R. G. Wilkins, J. Inorg. Nucl. Chem., 1958, 6, 161.

7 W. R. Mason, Coord. Chem. Rev., 1972, 7, 241-255.

8 K. Hindmarsh, D. A. House and R. van Eldik, Inorg. Chim. Acta, 1998, 278, 32-42.

9 L. Drougge and L. I. Elding, Inorg. Chem., 1985, 24, 22922297.

10 R. L. Rich and H. Taube, J. Am. Chem. Soc., 1954, 76, 26082611.
11 I. V. Znakovskaya, Y. A. Sosedova, E. M. Glebov, V. P. Grivin and V. F. Plyusnin, Photochem. Photobiol. Sci., 2005, 4, 897902.

12 L. I. Elding and L. F. Olsson, J. Phys. Chem., 1978, 82, 69-74.

13 L. I. Elding, Inorg. Chim. Acta, 1978, 28, 255-262.

14 M. Spitzer, F. Gartig and R. van Eldik, Rev. Sci. Instrum., 1988, 59, 2092-2093.

15 R. van Eldik, W. Gaede, S. Wieland, J. Kraft, M. Spitzer and D. A. Palmer, Rev. Sci. Instrum., 1993, 64, 1355-1357.

16 L. E. Cox and D. G. Peters, Inorg. Chem., 1970, 9, 19271930.

17 R. S. Livingston and W. C. Bray, J. Am. Chem. Soc., 1925, 47, 2069-2082.

18 A. Mohammad and H. A. Liebhafsky, J. Am. Chem. Soc., 1934, 56, 1680-1685.

19 C. Bender and H.-D. Brauer, J. Chem. Soc., Perkin Trans. 2: Phys. Org. Chem., 1999, 2579-2587.

20 L. I. Elding and L. Gustafson, Inorg. Chim. Acta, 1976, 19, 165-171.

21 M. M. Jones and K. A. Morgan, J. Inorg. Nucl. Chem., 1972, 34, 259-274.

22 R. van Eldik, T. Asano and W. J. le Noble, Chem. Rev., 1989, 89, 549-688. 